\title{
A Geography of Place: principles and application for defining 'eco-civic' resource governance regions
}

DAVID BRUNCKHORST \& IAN REEVE, University of New England, Australia

\begin{abstract}
River catchments have been the dominant form of regionalisation for natural-resource management in many countries since the 1980s. Local governments play a considerable role in planning with ever-increasing responsibilities for sustainable environmental management, planning and development controls. There has also been an increasing emphasis on community participation in resource management, which emphasises the need to re-examine the requirements for spatial definition of resource governance regions. This paper proposes three principles. First, the nature and reach of environmental externalities of resource use should determine the size and nesting of resource management regions. Second, the boundaries of resource governance regions should enclose areas of greatest interest and importance to local residents. Third, the biophysical characteristics of a resource governance region should be as homogenous as possible, which provides resource planning and management efficiencies. The paper describes a range of concepts and empirical techniques used to apply these principles to the derivation of a resource governance regionalisation of the State of New South Wales, Australia.
\end{abstract}

KEY WORDS Regionalisation; catchment management; community; resource governance; social catchment; eco-civic; nesting.

\section{Introduction}

In recent years, an increasing number of governments around the world have begun to struggle with rising social and environmental costs of the negative externalities of natural-resource management. As negative environmental externalities continue to emerge in rural Australia and as regional prosperity becomes increasingly dependent on the efficient management of these externalities, the costs of dysfunctional environmental management caused by inappropriate jurisdictional boundaries will continue to increase. Consequently, the point will be reached where these costs begin to overshadow any costs associated with inefficiencies of administration and service delivery that might be caused by local government or catchment management areas that are in the wrong geographical place and/or are too large or too small. In this situation, the location of jurisdictional boundaries for 
effective and efficient environmental management is a matter of some import and one that deserves careful analysis.

With growing emphasis on community engagement, there is also increasing understanding by both scientists and policy makers that many resource governance issues relate to the complex interdependencies of social and ecological systems operating at various scales (e.g. Slocombe 1993; Brown \& MacLeod 1996; Berkes \& Folke 1998). Concepts of federalism for efficiencies in ecological and economic management useful in simplifying complexity and assigning levels of responsibility have been employed to establish administrative and spatial units for planning and management (Waldo 1984; McGinnis 1999). The range of regional frameworks used in resource governance to date, including catchment or watershed arrangements, appear to have had limited success integrating resource management for sustainability (Johnson et al. 1999; Barham 2001; Carpenter \& Gunderson 2001; Blomquist \& Schlager 2005).

This paper argues that the placement of boundaries to define regions for integrated resource governance warrants more careful analysis than it has been accorded in the past. Recent experience and reviews mentioned above demonstrate a need to re-examine the question: What is a 'region' for resource governance? Also, what is required to optimise boundary placement for spatial definition of resource governance regions? This paper proposes three key principles considered to be of particular importance in defining spatial boundaries of regions for resource governance. In essence, the requirements are for regional boundaries that best capture the representation of 'place identity' or local areas of most interest to community residents (e.g. Brandenburg \& Carroll 1995; Cantrill 1998) together with similar resource characteristics of regional landscapes (Omernik 1995; Field et al. 2003), optimised as nested local to broad regional contexts might be able to deal with social-ecological interdependencies (Urban et al. 1987; Blomquist \& Schlager 2005).

Using the State of New South Wales in Australia, we briefly demonstrate the application of an empirical method for deriving a nested hierarchy of such regions that are consistent with these principles.

\section{Local government areas for resource governance}

Much of the environmental legislation introduced in Australia in the last 40 years functions either explicitly or indirectly to prevent, resolve or manage negative environmental externalities as they are initiated by the pressures on the environment of population, economic development and technology. New functions have been emerging for both State and local government as a consequence of this. Of particular relevance to the management of the land and water resources in rural areas is the growing range of functions being taken on by local government in planning and development, environmental management and environmental reporting.

Local government in New South Wales had its origins in central Sydney in the early nineteenth century. The Municipalities Act 1858 made it possible for municipal governance to be established outside the boundaries of the Sydney City Council. Any town, city, hamlet or rural district could be proclaimed a municipality if a petition was signed by a group of at least 50 ratepayers. A second Municipalities Act was passed in 1867, and incorporation of municipalities 
continued through the remainder of the nineteenth century at the initiation of citizens.

The Sydney Convention of 1904, comprising mayors of municipalities, Agricultural Societies, Farmers and Settlers' Associations, Pastures Protection Boards and Progress Associations, recommended the appointment of a commission to divide the State into municipalities and shires. A Local Government Areas Commission was constituted in January 1905 to create local government areas (shires) within the unincorporated areas of NSW, with the exception of the Western Division. The Commission was required, inter alia, to pay due consideration to community and diversity of interest, lines of communication, physical features, and the necessary expenditure of any proposed shire for bridges, roads and works of public utility (Maiden 1966).

The Local Government (Shires) Act of 1905 divided the Eastern and Central Divisions of New South Wales into 134 shires, the boundaries of which were determined on the basis of the Commissions' recommendations. Further legislative adjustments occurred. This act, and amendments in 1906 and 1907, was replaced by the Local Government Act of 1919 to bring a number of measures within one piece of legislation.

Throughout the twentieth century, the great technological and economic changes and changes in public policy have brought pressure for structural reform in local government (NSW Department of Local Government 2004). The rationale for structural reform has generally centred on 'efficiency' from a narrow economic perception of joining existing local government areas (Dollery \& Johnson 2005). Other efficiencies and alternatives are generally left out of such assessments. As an article in the Evening News yearbook in 1925 noted:

The present Shires were designed in the days of the horse and buggytheir size was governed by the ability to administer them with the then existing means of transport. The motor age has come and makes it possible to enlarge areas without prejudice to ease, effort and for efficiency of administration. (Cited in Anderson 1983, p. 16.)

The 1919 Act allowed that, in cases where local people raised objections to the Minister's proposals for boundaries, public inquiries could be held (Musgrave et al. 1985). The use of inquiries conducted by a single commissioner appointed by the Minister for a specific boundary issue continued until 1964, when a statutory authority, the Boundaries Commission, was established. Disbanded in 1980, the Commission was re-established in 1982, without the authority to make proposals for the alterations of local government boundaries (Anderson 1983).

Episodes of local government amalgamation and boundary change have continued in New South Wales, and other States, to the present day. The question of the location of boundaries however, has received very little attention other than in the context of debates about amalgamation of adjoining local government areas, administrative efficiency and economies of scale (see, for example, NSW Department of Local Government 2004).

\section{Water catchments for resource governance}

River catchments have become the dominant form of regionalisation for natural-resource governance in many countries. Modern integrated catchment 
management has its roots in early twentieth-century progressivism in the United States in the early twentieth century (Waldo 1984; Margerum 1995; Muskingum Water Conservancy District 2002). In the 1960s, new social movements concerned with environmental and civil rights issues led to increased demands for direct citizen participation in public policy making. Along with many areas of public policy, integrated catchment management responded with a shift from technocratic planning to various forms of participative planning. In Australia, this shift took place in the late 1980s and early 1990s, with little consideration either of the implications for the definition of resource governance regions or of the considerable body of theory in the social sciences that is relevant to the regionalisation issue, such as central place theory (Christaller 1933), gravity modelling (Carrothers 1956), theories of place attachment (Kemmis 1990; Altman \& Low 1992; Cuba \& Hummon 1993) and hierarchy theory (Pattee 1973). During the same period, local government has increasingly been given a considerable responsibility for local environmental planning and management.

During the 1990 s, academic interest in public participation in natural-resource governance, continued to grow (e.g. review by Buchy et al. 2000), as has the development, empirical testing and refinement of theories of place attachment (Feld \& Basso 1996; Wilkinson 2000; Stedman 2003). There has also been increasing understanding of the role that place and community play in influencing natural-resource politics and management (e.g. Beckley 1995; Shannon 1998; Cheng et al. 2003; Field et al. 2003; Schusler et al. 2003; Carr 2004; Parisi et al. 2004).

While this conceptual and theoretical development has burgeoned in the last 10 years, catchments have nevertheless remained the dominant administrative unit for regional natural-resource governance in Australia and elsewhere (Reeve et al. 2002a, b; Phelps 2003). Within the integrated catchment-management literature, most authors accept unquestioningly that catchments should form the areal units within which natural-resource governance takes place. Others (e.g. McGinnis et al. 1999; Webler \& Tuler 1999) make a case that smaller river catchments can sometimes form a natural unit encompassing cultural and social commonalities.

However, there is a growing weight of argument against the assumption that catchment-based regions or local government areas automatically incorporate all resource governance issues and their communities of interest (Omernik \& Bailey 1997; Getches 1998; Blomquist \& Schlager 2005; O’Neill 2005). Johnson et al. (1999), Brunckhorst (2000, 2002) and Parisi et al . (2003, 2004) have also pointed out that regions of similar biophysical attributes and climate have little correlation to either watershed topography or areas of interest to land-use communities. Barham (2001) argued that processes of democratic deliberation that have evolved over long periods of time prior to the emergence of modern environmentalism cannot necessarily be fitted to catchment boundaries.

In Australia, several authors have argued that the boundaries of communities that might form natural units within which resource governance issues are negotiated and resolved rarely coincide with physical catchment boundaries (Brunckhorst 2000; Ewing 2003; Lane et al. 2004; O’Neill 2005). Syme et al. (1994) went so far as to suggest that organisation of community involvement on catchment boundaries would act against the achievement of the stated goals and purposes of integrated catchment management. 


\section{Social catchments in resource governance}

Theories surrounding 'place' and 'community' have gained increasing empirical support and refined definitions in recent years (Wilkinson 2000; Cheng et al. 2003; Stedman 2003; Parisi et al. 2004). There has also been increasing understanding of the real role 'place' and 'community' play in influencing natural-resource politics and management (see, for example, Shannon 1998; Schusler et al. 2003; Carr 2004; Parisi et al. 2004). Indeed, an examination of the underlying theories of landscape ecology and demography by Field et al. (2003) highlights the need to refine techniques for the spatial definition of such 'social catchments' in order to truly understand landscape patterns and processes.

A concept of 'social catchments' has also developed in Australia. Graeme Hugo and Peter Smailes, at the University of Adelaide, have been refining and operationalising the concept since the 1970s. In recent years, two other groups in Australia have started working in this area: Mark Fenton, at James Cook University in Townsville, and the authors of this paper, at the University of New England in Armidale. A review of these concepts and techniques was undertaken by Colin Macgregor at the Australian Bureau of Rural Sciences. The publication of this work (Hugo et al. 2001, p. 49) defined social catchments as:

The territory occupied by a group of households and individuals who are in some form of regular interaction and which the inhabitants identify as 'their' community or region.

Social catchments, so defined, are almost invariably centred on one or more urban areas or central places. The concept owes much to central place theory (Christaller 1933) and gravity modelling (Carrothers 1956), particularly with respect to the idea that social catchments may form nested hierarchies. However, in operationalising the concept, the three groups in Australia have taken distinctly different directions (Hugo et al. 2001). The method used by the University of Adelaide group (e.g. Smailes 1999) involves mail surveys of people living outside urban centres. These surveys gather information about the spatial extent of the community with which people identify, their attitudes about this community and the normal place of purchase of selected goods and services. This information is used to identify the 'rural neighbourhoods' recognised by respondents, and larger 'rural communities' which show the areas over which respondents travel to make purchases.

The Town Resource Cluster method developed by Fenton et al . (2000) is based on the calculation of dependency measures between towns. These measures are derived from interviews and secondary data relating to business expenditure, employee expenditure, employee residential locations, social infrastructure services and facilities and social networks. This enables groups of towns with high interdependency to be identified (Hugo et al. 2001). The method has been applied to regional economies based on particular natural resources, such as fisheries, water resources or timber.

By the time the review by Hugo et al. (2001) was completed, the authors of this paper had developed a technique for deriving what were termed 'social-ecological frameworks', herein called 'Eco-Civic' regions (Brunckhorst \& Rollings 1999; Brunckhorst 2000, 2002; Brunckhorst \& Coop 2001). This involved 
sending a mail questionnaire to a spatially even sample of residents in a region, asking them to mark on the included map the location of their residence and to draw a line around the region that they regarded as 'their community'. This information was digitised as shape files, and the 'community areas' summed to produce a surface. The 'valleys' on this surface represented areas that were regarded as part of their community by relatively few respondents. The shape of the surface was compared with a map of bioregions to propose resourcemanagement regions bounded by the 'valleys' on the surface and with relatively homogenous biophysical characteristics.

\section{Regionalisation principles for resource governance}

Despite the mounting criticisms of catchments as natural-resource governance regions, and the growing conceptual and theoretical development in socio-spatial aspects of natural-resource governance, there has been surprisingly few attempts to propose and apply empirical techniques of regionalisation that might address some of these criticisms and build on this growing body of theory (see Omernik \& Bailey 1997; Brunckhorst 2000).

An exception, and the subject of this paper, is the major study (2003-2004) by the Institute for Rural Futures to derive a nested hierarchy of resource governance regions for the rural part of the State of New South Wales in Australia (Brunckhorst et al. 2004). For this study, it was necessary to distill from the growing literature on socio-spatial aspects of natural-resource governance some principles that could inform the detailed methodological development. The three principles that were chosen are now described.

\section{Principle 1: The nature and reach of the environmental externalities of resource use determine the size and nesting of resource governance regions}

The need for collective decision making about natural-resource use derives from the fact that one person's use of natural-resources impacts upon other people. The spatial extent of these environmental externalities can range from the local (e.g. noise pollution), to the regional (e.g. groundwater extraction from regional aquifers), to the national or global (e.g. carbon dioxide emissions). If those who create, and those who are affected by these externalities, are to be represented in collective decision making, then the resource governance region within which this takes place has to be of a similar scale as the reach of the externalities (see McGinnis 1999; Cole 2002).

Many environmental externalities operate simultaneously across a range of scales. For example, vegetation clearing for agriculture on a farm might result in outbreaks of salinised land on adjacent farms, and an increase in salinity of surface waters which has impacts on urban water users $1000 \mathrm{~km}$ downstream. For this reason, it is likely that in most areas, resource governance regions will need to be nested, with smaller regions (dealing with local problems) nested within larger regions (dealing with environmental externalities with a longer reach). The principles by which nested resource governance regions might operate are beyond the scope of this paper (see McGinnis 1999; Reeve 2003; Marshall 2004). 
Principle 2: The boundaries of natural-resource governance regions should pass through areas of minimum collective interest to local people.

People are quite capable of identifying the locality of their 'place attachment' or the area they regard as their community (Hillery 1955; Kemmis 1990; Altman \& Low 1992; Cuba \& Hummon 1993; Brandenburg \& Carroll 1995; Wilkinson 2000; Hobbs et al. 2002; Cheng et al. 2003; Stedman 2003). The work of Coop (2003) demonstrated that there is a high degree of spatial conformity between the areas regarded as the location of one's community, the areas regarded as acceptable for the residential location of one's elected representative in local government, the area of one's local social networks and interactions, and the areas within which one would wish to be consulted about resource governance decisions affecting those areas. Such an area is referred to here as a 'community area'. While people will have interests in distance places, too, their local community area is the locus of substantial social and economic interaction with other residents, and of interaction with a natural-resource base.

Almost any point in the landscape will lie within one or more community areas belonging to the people living in the vicinity of that point. A point in the landscape that lies within a large number of overlapping community areas is a point in which a correspondingly large number of people have an interest. Resource governance decisions affecting this point in the landscape will have to consider the interests of this large number of people. If the boundaries of natural-resource governance regions cut through such an area, local community participation and engagement will be greatly compromised. Indeed, it is likely that many residents will feel dissatisfied with consultative processes and the representation of their interests (Knight \& Landres 1998; Shannon 1998; Reeve et al. 2002b; Parisi et al. 2003, 2004).

Other points in the landscape will lie within relatively few community areas. If the boundaries of natural-resource governance regions pass through these parts of the landscape, then a minimum number of people will be in a situation in which their community area is divided between one or more resource governance regions. For this reason, the second principle proposes that resource governance boundaries should pass through points that lie within relatively few community areas.

Principle 3: For effective and efficient natural-resource governance, it is important that the administrative region within which management occurs contains a relatively homogeneous set of landscapes - climate, ecological characteristics and resources

The biosphere can be divided into continents and oceans, and the former further subdivided into broad continental regions. These can be subdivided into ecoregions and landscapes, and landscapes into ecosystem components, and further subdivided into patches or structural units and so on (Wiken 1986; Omernik 1987, 1995; Bailey 1996; Brunckhorst 2000). Across broad continental regions, patterns are generally observable at various spatial scales where similar organisms or biophysical attributes occur together. These mosaics are composed of units within which internal homogeneity is relatively high. When similar recurring ecological communities are replaced by a different set of recurring natural units, landscape boundaries can be observed and their underlying causes inferred fairly accurately (Forman \& Godron 1981, 1986; Hansen \& di Castri 1992; Forman 1995). 
Considerable gains in efficiency can be made if planning, priority setting and resource governance actions take account of these boundaries (Reid \& Murphy 1995; Johnson et al. 1999; McGinnis et al. 1999; Brunckhorst 2000; Field et al. 2003).

\section{Empirical derivation of resource governance regions}

The method developed in this study consisted of three major components, and required the formulation of the concept of a 'social surface' (described below; see also Brunckhorst et al. 2004, 2006):

(1) derivation of a hierarchy of biophysical regions (to satisfy principles 1 and 3);

(2) derivation of a social surface and a hierarchy of 'civic' regions defined by the 'valleys' in social surface (to satisfy principles 1 and 2); and

(3) optimisation of the boundaries of the two hierarchical regionalisations so that all three principles are satisfied to the maximum degree possible.

The following sections describe the methods followed and results for each of these three components, with an emphasis on the social surface and civic regions.

\section{Biophysical regionalisation}

The biophysical regionalisation was based on elevation, soil moisture, soils and climate data at scales of $1 \mathrm{~km}$ or finer, using the ERDAS Imagine 8.5 classification routine (for details, see Brunckhorst et al. 2004). The result was a hierarchical biophysical regionalisation comprising eight major regions (level 1), each of which was divided into sub-regions (level 2). The level 2 sub-regions were further subdivided into two or more level 3 sub-regions. The hierarchical ecoregional boundaries of the biophysical regionalisation are shown in Figure 1.

\section{Social surface and civic regionalisation}

The methods currently being used in Australia for the derivation of social catchments are highly dependent on the acquisition of primary data from surveys of residents and, for economic reasons, are infeasible to apply on a large scale (Hugo et al. 2001; Coop 2003).

A modelling approach was developed that could use mostly secondary data, and which utilised insights from theories of place and cognitive mapping (e.g. Hillery 1955; Tuan 1974; Altman \& Low 1992; Cuba \& Hummon 1993; Austin 1994; Kearney \& Kaplan 1997; Hobbs et al. 2002; Cheng et al. 2003). This modelling approach was founded on the observation from the primary data gathered in earlier work focused on northern New South Wales (Brunckhorst \& Coop 2001; Coop 2003; Brunckhorst et al. 2006) showing that the community areas that people drew on a map of their region approximated ellipses in outline, with sizes ranging from a few kilometres across the shortest dimension to over a hundred kilometres. For the majority of rural residents, the ellipse was defined by their place of residence (home point) at one end of the ellipse and a town at the other end. For residents in smaller towns or villages, the elliptical community area generally included the nearest larger town, while for residents in larger towns, the community area included one or more 


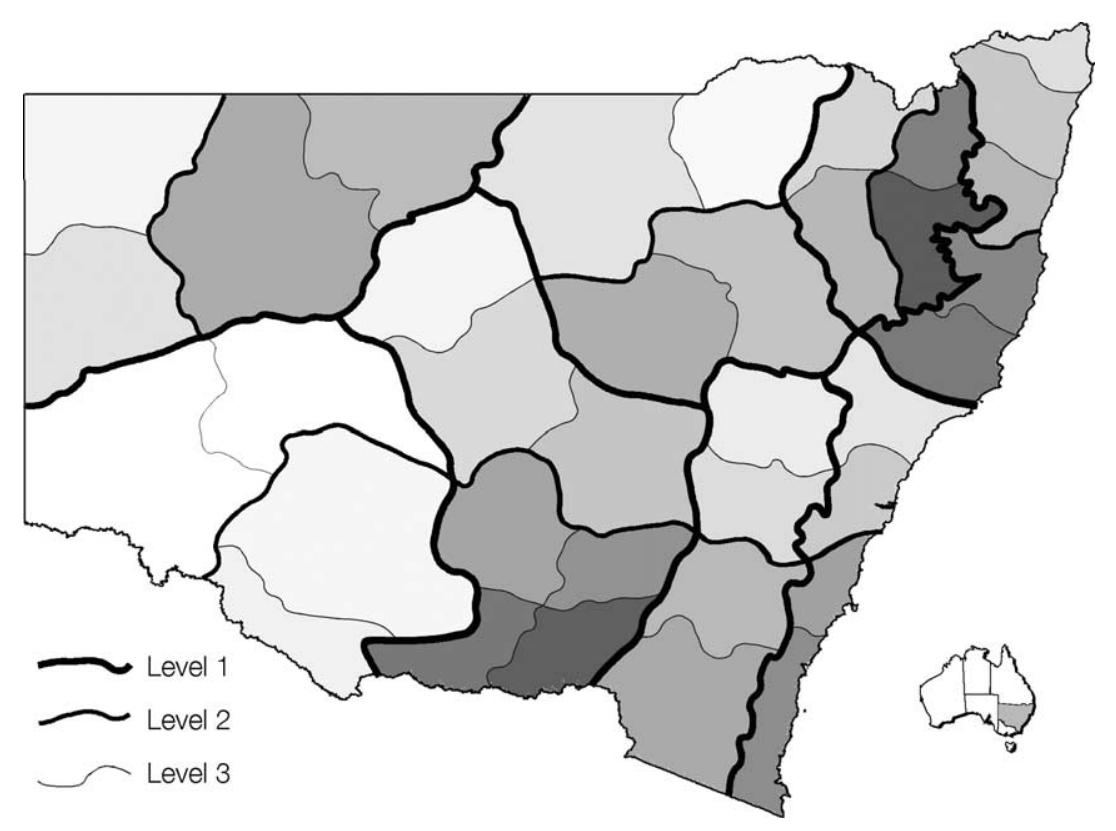

FIGURE 1. Boundaries of the hierarchical biophysical regionalisation of the State of New South Wales.

smaller towns in the region, usually along major highways. Community areas tended to be larger in the more sparsely settled regions of northern New South Wales, and smaller in the more densely settled coastal regions. This suggested that it would be possible to model community areas by populating the State of New South Wales with simulated home points, and attaching an elliptical simulated community area to each home point, appropriately sized and orientated according to the location of towns of various sizes in the vicinity (Brunckhorst et al. 2004, 2006).

\section{Simulating home points}

A spatial resolution of $1 \mathrm{~km}$ had been set for the study which led to a spacing of simulated home points at intervals of $500 \mathrm{~m}$ or less. The Census Collection Districts (CCDs) for New South Wales were ranked by population density and the population fraction for simulation for the least dense CCD set to a value that would provide for distances of $500 \mathrm{~m}$ between simulated home points when that fraction of the population of the CCD was uniformly distributed across the geographical extent of the CCD. The required population fraction for the least dense CCD was found to be 0.66 . However, if this value were to be used in densely settled areas, this would result in far more simulated home points than needed to generate the social surface described below. Accordingly, a continuously variable population fraction was used, where the fraction was an inverse function of population density. This resulted in one simulated home point per CCD in metropolitan areas and large cities. The procedure described above resulted in 14339 simulated home points spread across New South Wales. 


\section{Simulating community areas}

Simulated elliptical community areas, sized and oriented according to the factors described above, were placed on each of these home points. New South Wales was divided into five regions, each region having a different mean community area size. These mean sizes were chosen to reflect the variation in community area size known from the earlier Northern NSW study (Brunckhorst \& Coop 2001; Coop 2003 Brunckhorst et al. 2006). As community areas were generated by the model in each region, they were randomly varied in size to give a size distribution similar in shape to that found in the Northern NSW primary data, with a mean community area size equal to that set for the region.

The second transformation of the simulated community areas was to orientate them such that they included one or more towns in the vicinity of the home point. To avoid boundary effects in regions close to the New South Wales border, towns in Queensland, South Australia and Victoria were included among the towns influencing the orientation of generated community areas.

The final step in the modelling procedure was to assign each simulated community area a height of one unit in a third dimension at right angles to the north-south and east-west dimensions of the map of New South Wales. Working in this three-dimensional space, the simulated community areas were summed to produce a 'social surface'. High points on this surface corresponded to points that lay within the community areas of relatively large numbers of people (strictly, large numbers of simulated home points). Low points on the surface corresponded to points that lay within the community areas of relatively few people. As proposed in Principle 2, above, it is these low points in the social surface that are suitable areas through which resource governance region boundaries might pass. The social surface obtained by summing the elliptical community areas on each of the 14339 simulated home points is shown in oblique view in Figure 2.

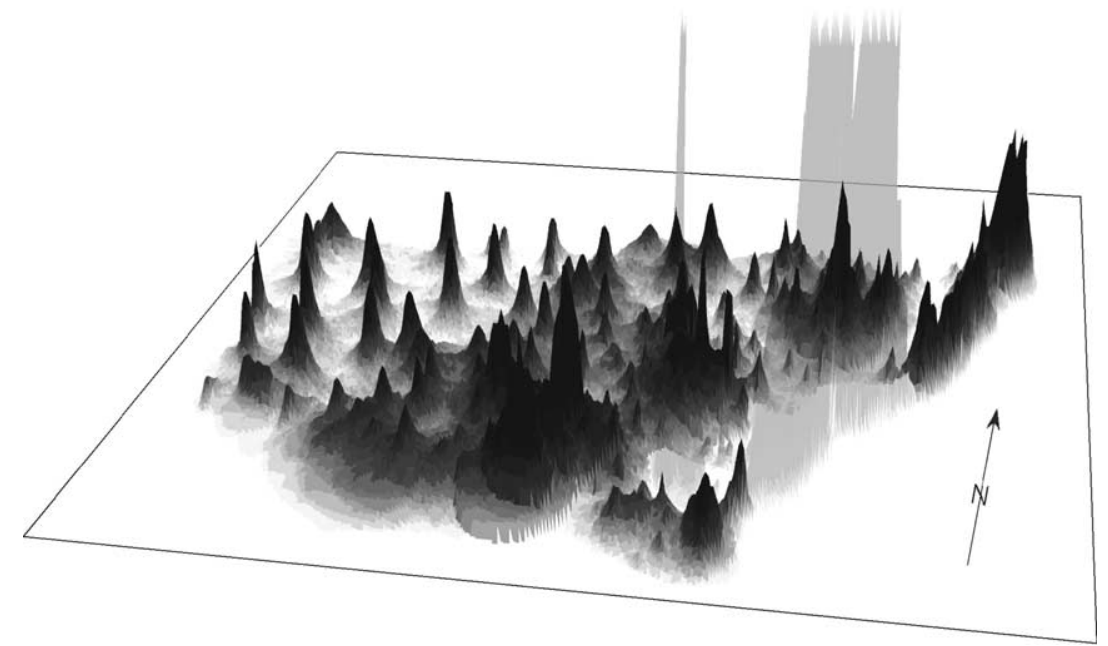

FIGURE 2. Simulated social surface for New South Wales. With the exception of the Sydney and Canberra regions, darker areas indicate higher elevations of the surface. The peaks in the surface representing Sydney and Canberra have been truncated and rendered semitransparent to avoid obscuring the parts of the surface behind these peaks. 


\section{Deriving a hierarchy of civic regions}

To produce a hierarchy of regions based on the simulated social surface, it is necessary to locate major and minor 'valleys' in the surface. Boundaries based on the major 'valleys' will define larger level 1 regions, and boundaries following the 'valleys' within these regions will define the smaller level 2 sub-regions. Once again, boundaries on minor 'valleys' within the level 2 sub-regions will define the yet smaller level 3 sub-regions.

The Hydrological Modelling Tool in ESRI ArcView 3.2 was used to produce a 'drainage network' on the modelled social surface. 'Valleys' at the lower 'altitudes' of the modelled social surface indicate possible locations for level 1 boundaries, those in the middle 'altitudes' level 2 boundaries, and those at the upper 'altitudes' level 3 boundaries. In some areas, the 'topography' of the social surface did not necessarily give a strong indication as to the placement of boundaries. This was a consequence of broad, shallow 'valleys' in the surface, or the presence of several 'valleys' in close proximity that were equally good candidates for the location of a boundary. For this reason, a telephone survey of a number of community organisations with hierarchical structures of local, regional and State branches was undertaken. Use of 'key informants' is an efficient way of gathering surrogate data or for 'ground-truthing' as used here (Parisi et al. 2002; Cheng et al. 2003). Smailes (1987) and Tonts and Atherley (2005) have demonstrated the important role that sport plays in the structure of rural communities and regions and the spatial expansion of interacting (or amalgamated) sporting organisations. A total of 403 interviews with office bearers in the Country Women's Association, the Hockey Association, the Soccer Association and the Netball Association were completed. Interviewees were asked about the localities in their region where their organisation interacted with similar organisations as part of social activities and/or sporting competitions. Information from the telephone survey of community organisations and the 'drainage network' was combined to produce a three-level hierarchical regionalisation of the modelled social surface, shown in Figure 3.

\section{Validation of the hierarchy of civic regions}

Recent studies (Brunckhorst \& Coop 2001; Coop 2003; Brunckhorst et al. 2006) provided an empirically measured social surface and associated set of civic regions for north-eastern New South Wales, against which the modelled civic regions could be compared. A classification matrix was used to record, for each civic region, the proportion of home points that were assigned to the same civic region when the modelled surface is used to derive the boundaries between the regions (Brunckhorst et al. 2004, 2006). The level of agreement (Kappa statistic, see Carletta 1996) between the modelled boundaries and the measured boundaries in north-eastern New South Wales was extremely good, with correct classifications of more than 98.6 per cent of the 1973 home points in the region for which measured data were available $(\kappa=0.982, p<0.0005)$.

\section{Eco-civic optimisation}

The boundaries that define the biophysical regionalisation (Figure 1) do not necessarily coincide with the boundaries of the civic regionalisation (Figure 3), 


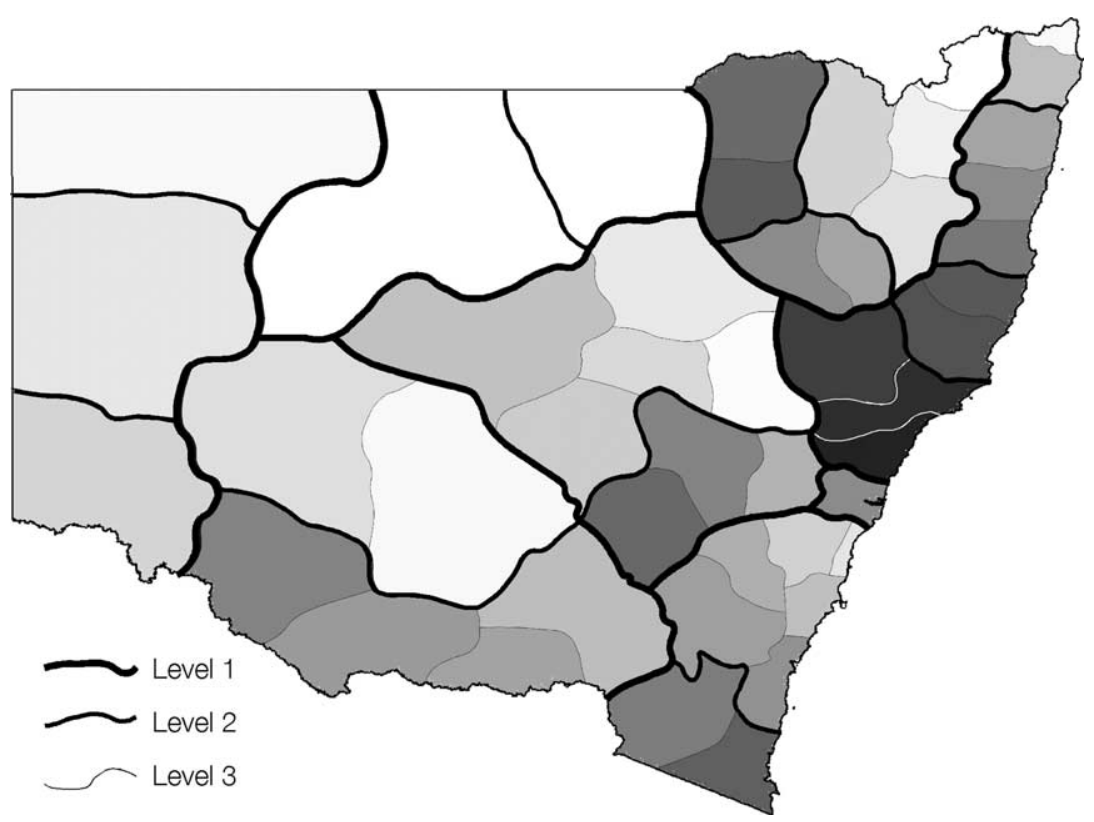

FigURE 3. Hierarchy of civic regions derived from the simulated social surface.

although the coincidence is fairly good along the eastern escarpment of the northern tablelands. This is because a sparsely settled area coincides with a major climatic, floral and faunal discontinuity in the landscape.

In many areas, it is necessary to adjust the boundaries of the civic regions to bring them into closer coincidence with the boundaries of the biophysical regionalisation. Flexibility in options for boundary placement is possible because the 'valleys' in the social surface can be quite broad. This is particularly so for the 'valleys' at lower 'altitudes' in the social surface. A boundary can therefore be moved reasonable distances within the confines of a 'social valley', without causing a significant increase in the number of community areas that are intersected by the boundary (Brunckhorst et al. 2004, 2006). At broader scales, therefore (i.e. level 1), the optimisation routine can give more weight to the biophysical boundaries. However, at finer scales (i.e. level 3), it is necessary to ensure that the optimisation routine does not shift boundaries into relatively high areas on the social surface.

The process of optimising boundaries to take account of the above considerations is termed 'eco-civic optimisation', and the resulting set of regions is termed an 'ecocivic regionalisation' (Brunckhorst et al. 2004, 2006). The eco-civic regionalisation for New South Wales is shown in Figure 4.

\section{Comparing the performance of regions}

For any given administrative region, some community areas will be wholly within the region boundary, while others will be intersected by the region boundary. The proportion of people's community areas that are wholly within a region boundary, compared with the total number of people living within that boundary, provides an index of the performance of the particular resource governance region in terms of its ability to include the areas that are of interest to residents. 


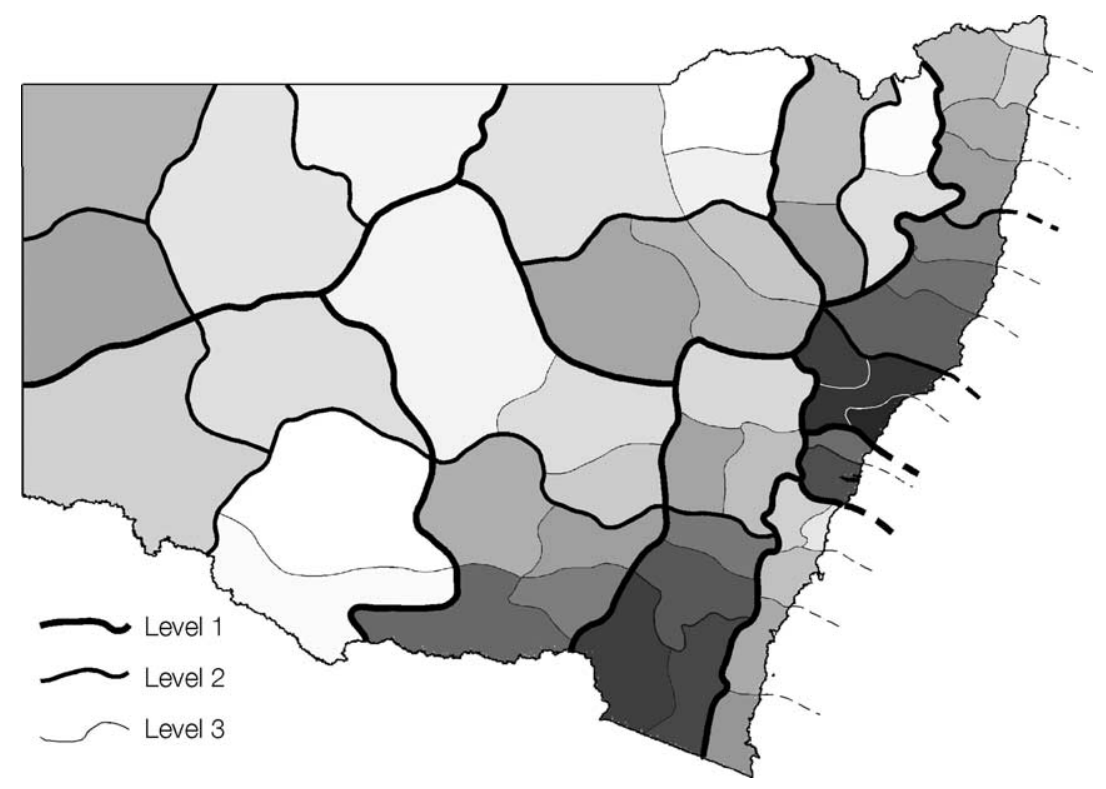

FIGURE 4. Hierarchy of eco-civic regions for New South Wales, following optimisation of the boundaries of the biophysical and civic regionalisations.

This index is termed the 'Community Capture Index' (CCI). The CCI provides a means of comparing the performance of different regions in terms of the extent to which people's community areas are intersected by region boundaries (Brunckhorst et al. 2004, 2006). In conformity with Principle 2, above, a regionalisation with boundaries that intersect fewer community areas (higher value of the CCI) is preferable to a regionalisation that intersects a greater number of community areas (lower value of CCI).

Figure 5 plots the CCIs for the three levels of the eco-civic regionalisation, and for a range of current administrative regions in New South Wales, including the Catchment Management Authority (CMA) regions which are based on catchment boundaries. The figure demonstrates that the current administrative boundaries and those of the CMAs are not in the best locations if the intersection of people's community areas by these boundaries is to be minimised. If the boundaries of the CMAs are overlaid on the boundaries of the level 2 eco-civic regions (Figure 6), it can be seen that these catchment-based boundaries are a poor fit with both the areas of community interest and the ecoregions.

\section{Conclusions}

The emergence of catchments and watersheds in the last three decades as the dominant method to delineate regions for resource governance has assumed that soils, vegetation, other biodiversity, land use and ground water, along with community engagement and collective action, best occur within such regions. Accordingly, there have been various critiques of catchment boundaries as spatial frameworks for integrating multiple resource governance. In practice, catchment management has a history of inefficiency, inappropriate monitoring and high transaction costs associated with it (see also Stokols \& Shumaker 1981; 


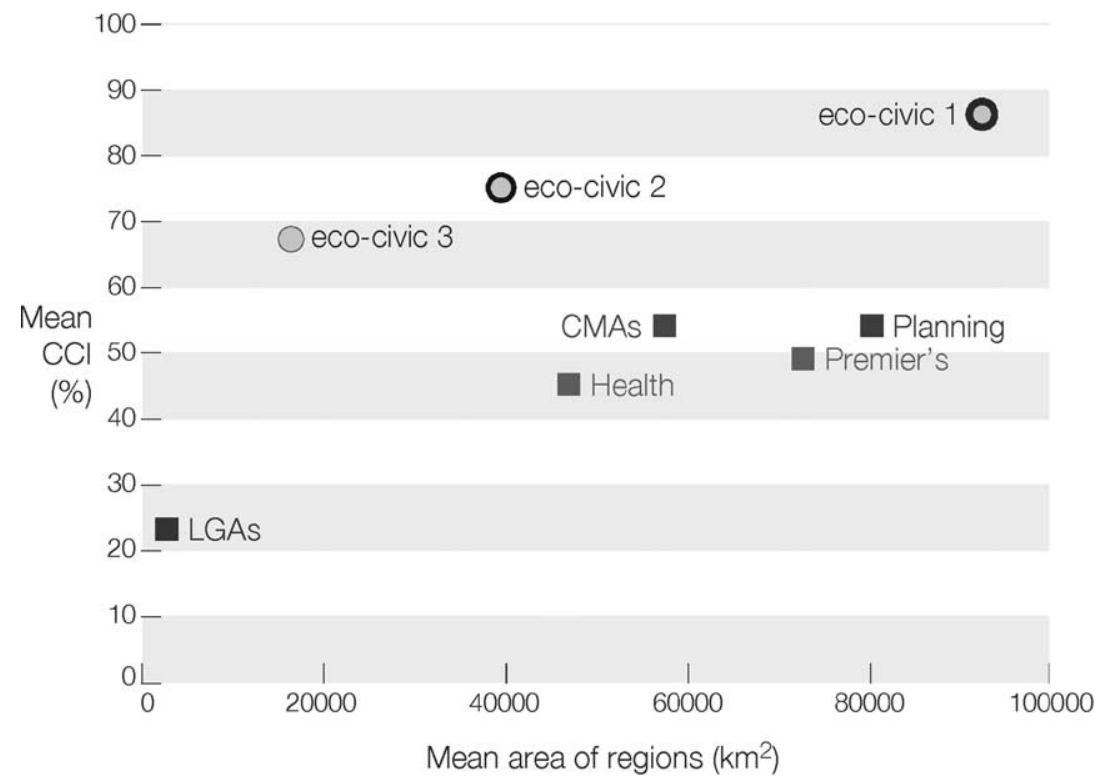

Figure 5. Mean Community Capture Index (CCI) plotted against mean area of regions for a range of administrative regions.

Syme et al. 1994; Minami \& Tanaka 1995; Omernik \& Bailey 1997; Getches 1998; Brunckhorst 2000; Barham 2001; Lane et al. 2004; O’Neill 2005). At least part of the reason for these shortcomings is that catchments usually do not represent either the 'place attachment' and communities of interest or the ecological resource base very well.

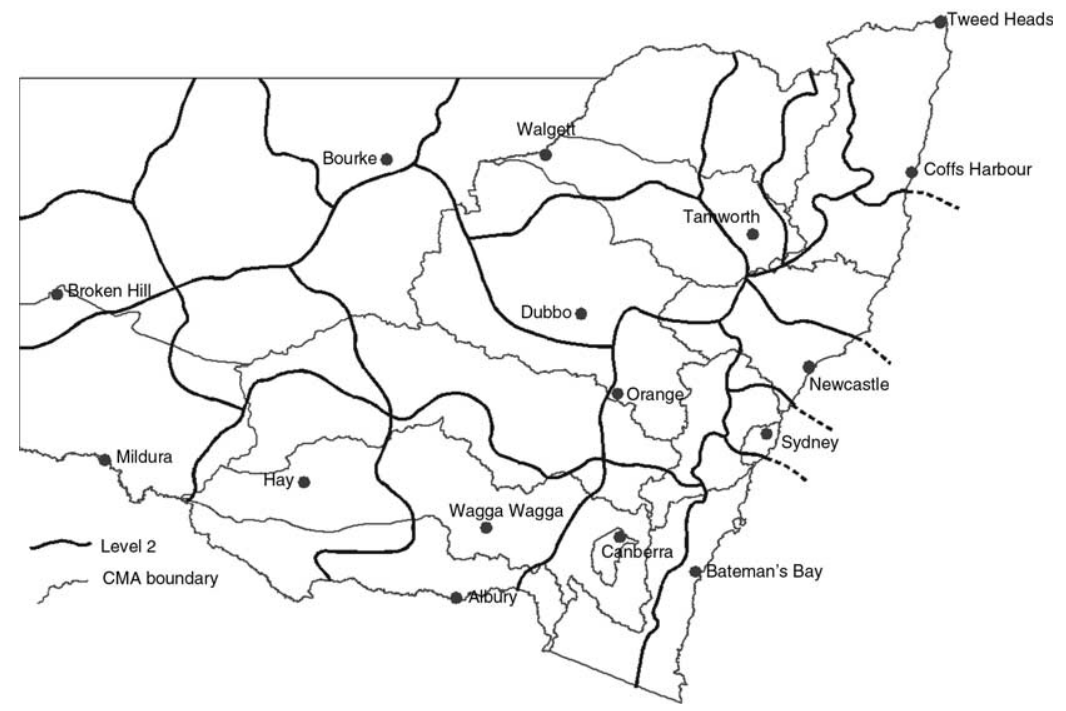

FIGURE 6. Boundaries of Catchment Management Authorities and the level 2 eco-civic regionalisation showing lack of representation of area of interest to land-use communities and environmental variables. 
This paper proposes three principles which can underpin the development of regionalisations for government administration of, and community participation in, natural-resource governance. In summary, these principles relate to the spatio-social context representing communities of interest, optimised for homogeneity of the ecological landscape, and spatially bounded in a nested hierarchy to facilitate scaling of institutional arrangements for management of externalities. While some small catchments and watersheds might possess these characteristics, many do not.

The majority of non-metropolitan local government areas do not reflect these characteristics either, especially in relation to local to regional 'communities of interest' in the twenty-first century (although this has long been recognised, for example Hillery 1955; Jones 1977; Walmsley 1977; Smailes 1987; Fulcher 1989; Cuba \& Hummon 1993; Brunckhorst 2000, 2002; Cheng et al. 2003). Nevertheless, Dollery and Crase (2004) criticised our approach from a neo-classical economics view of local government. Clearly, our study is not an economic study, but we would maintain that local governments play a much larger and critically important role in land-use decisions and environmental planning and management than in any role they might have in local economies. We would also suggest that policy makers would be wise to match local government and other service delivery 'regions' with the area of interest to local residents for representation, economic activity, resource activity and civic engagement (see also Cuba \& Hummon 1993; Brunckhorst 2000; Cheng et al. 2003). Most local government areas in NSW, indeed Australia, are still based on boundaries established a century ago when transport and communications were very different. This study demonstrates quite clearly that the majority of these boundaries (including amalgamated LGAs retaining previous boundaries) are in the wrong place and do not reflect current community interactions, communications, local travel and the area of interest for engagement in local civic affairs.

The study has established a practical method to produce a hierarchical regionalisation that will satisfy the proposed principles. Synthesis of primary data may well be more accurate, but such spatially even survey design, application and data handling is prohibitively expensive and time-consuming. The method used was based on established theory, a sub-set of primary data and readily available secondary data, with a small validatory telephone survey of rural community associations which, through their structure and activities, provide information to support the interpretation of the social surface. This approach involves identifying where boundaries between resource governance regions should pass so as to minimise the fragmentation of the areas of the landscape with which local people identify and in which they have an interest. Boundary placement is further optimised to ensure that natural-resource issues and ecosystem functions are as homogenous as possible within the regions defined by the boundaries. The study has also proposed an index (the Community Capture Index) that provides a numerical measure of the extent to which boundaries cut through areas of the landscape with which people identify and in which they have an interest. Application of the eco-civic methodology to design of local to regional institutions for resource governance could also be useful in the review of local government areas, regional planning. It provides a greater integrative capacity to design spatial frameworks for local governance to plan and manage towards sustainability across 
multiple scales of human living areas, communities, and natural-resource management including water management.

\section{Acknowledgements}

The NSW Department of Lands and, Land and Water Australia have funded different elements of this research. Our conclusions do not necessarily reflect the policies of these organisations. We greatly appreciated assistance in data analysis, GIS and mapping, and review from Karl Bock, Phil Coop, Phil Morley, Judith McNeill, Brendan Doyle, Graham Marshall and Richard Stayner.

Correspondence: David Brunckhorst, Institute for Rural Futures and UNESCO Centre for Bioregional Resource Management, University of New England, Armidale, NSW 2351, Australia. E-mail: dbrunckh@une.edu.au

\section{REFERENCES}

Altman, I. \& Low, S.M. (eds) (1992) Place attachment, Plenum Press, New York.

ANDERson, K.H. (1983) 'The role of the Boundaries Commission', Local Government Administration 20, pp. 15-19.

Austin, D.E. (1994) 'Incorporating cognitive theory into environmental policymaking', Environmental Professional 16, pp. 262-74.

BaILEy, R.G. (1996) 'Multi-scale ecosystem analysis', Environmental Monitoring and Assessment 39, pp. 21-24.

BARHAM, E. (2001) 'Ecological boundaries as community boundaries: the politics of watersheds', Society \& Natural Resources 14, pp. 181-91.

BECKLEY, T.M. (1995) 'Community stability and the relationship between economic and social well-being in forest-dependent communities', Society E Natural Resources 8, pp. 261-66.

Berkes, F. \& Folke, C. (eds) (1998) Linking social and ecological systems: Management practices and social mechanisms for building resilience, Cambridge University Press, Cambridge.

Blomquist, W. \& Schlager, E. (2005) 'Political pitfalls of integrated watershed management', Society \& Natural Resources 18, pp. 101-17.

Brandenburg, A.M. \& CARroll, M.S. (1995) 'Your place, or mine: the effect of place creation on environmental values and landscape meanings', Society $\mathcal{E}$ Natural Resources 8, pp. 381-98.

BROWN, J. \& MACLEOD, N. (1996) 'Integrating ecology into natural resource management policy', Environmental Management 20, pp. 289-96.

BRUNCKHORST, D.J. (2000) Bioregional planning: Resource management beyond the new millennium, Harwood Academic, Taylor \& Francis, Amsterdam.

BRUNCKHORST, D.J. (2002) 'Institutions to sustain ecological and social systems', Ecological Management \& Restoration 3, pp. 109-17.

BrunckHorst, D.J. \& CoOP, P. (2001) 'The influence of social eco-logics in shaping novel resource governance frameworks', in Lawrence, G., Higgins, V. \& Lockie, S. (eds) Environment, society and natural resource management: Theoretical perspectives, Edward Elgar Academic Press, Cheltenham, UK, pp. 84-103.

Brunckhorst, D.J. \& Rollings, N.M. (1999) 'Linking ecological and social functions of landscapes: I. Influencing resource governance', Natural Areas fournal 19, pp. 34-41.

BRunckHorst, D., CoOP, P. \& ReEve, I. (2006) 'Eco-civic optimisation: a nested framework for planning and managing landscapes', Landscapes and Urban Planning 75, pp. $265-281$. 
Brunckhorst, D., Reeve, I. \& Coop, P. (2004) Eco-civic regionalisation for New South Wales, published report to the New South Wales Government, New South Wales Department of Lands and Institute for Rural Futures, University of New England, Armidale, also available at www.ruralfutures.une.edu.au/projects/landscape/ecocivic.htm (accessed 7 February 2006).

Buchy, M., Ross, H. \& Proctor, W. (2000) 'Enhancing the information base on participatory approaches in Australian natural resource management', in Land and Water Australia (ed.) Natural Resources Management-People and Policy, Land and Water Australia, Canberra, pp. 1-78.

CANTRILl, J.G. (1998) 'The environmental self and a sense of place: communication foundations for regional ecosystem management', fournal Applied Communication Research 26, pp. 301-318.

Carletta, J. (1996) 'Assessing agreement on classification tasks: the kappa statistic', Computational Linguistics 122, pp. 249-54.

Carpenter, S.R. \& Gunderson, L.H. (2001) 'Coping with collapse: ecological and social dynamics in ecosystem management', Bioscience 51, pp. 451-57.

CARr, A.J. (2004) 'Why do we all need community science?', Society E Natural Resources 17, pp. $841-49$.

CARrothers, G. (1956) 'A historical review of the gravity and potential concepts of human interaction', fournal of American Institute of Planners 22, pp. 94-102.

Cheng, A.S., KRUGer, L.E. \& DANiELs, S.E. (2003) "Place" as an integrating concept in natural resource politics: propositions for a social science research agenda', Society $\mathcal{E}$ Natural Resources 16, pp. 87-104.

Christaller, W. (1933) Central places in southern Germany (translated by C.W. Baskin, 1966), Prentice-Hall, Englewood Cliffs, NJ.

Cole, D.H. (2002) Pollution and property: Comparing ownership institutions for environmental protection, Cambridge University Press, Cambridge.

Coop, P. (2003) Eco-civic landscapes: Capturing civic interest in multi-scale natural resource management frameworks, unpublished Ph.D. thesis, University of New England, Armidale, NSW.

Cuba, L. \& Hummon, D.M. (1993) 'A place to call home: identification with dwelling, community, and region', Sociology Quarterly 34, pp. 111-31.

Dollery, B. \& Crase, L. (2004) 'A critical note on 'eco-civic regionalisation' as the basis for local government boundaries in Australia', Australian Geographer 35, pp. 289-99.

Dollery, B. \& Johnson, A. (2005) 'Enhancing efficiency in Australian local government: and evaluation of alternative models of municipal governance', Urban Policy $\mathcal{E}$ Research 23, pp. $73-85$.

EwING, S. (2003) 'Catchment management arrangement', in Dovers, S. \& Wildriver, S. (eds) Managing Australia's environment, Federation Press, Sydney, pp. 393-412.

Feld, S. \& Basso, K.H. (1996) Senses of place, School of American Research Press, Santa Fe.

Fenton, M., Coakes, S. \& Marshall, N. (2000) Social assessment in natural resource management: The development and application of town resource cluster analysis (TRCAnalysis), Mimeo.

Field, D.R., Voss, P.R., Kuczenski, T.K., Hammer, R.B. \& Radeloff, V.C. (2003) 'Reaffirming social landscape analysis in landscape ecology: a conceptual framework', Society \& Natural Resources 16, pp. 349-62.

Forman, R.T. (1995) Land mosaics: The ecology of landscapes and regions, Cambridge University Press, Cambridge.

Forman, R.T. \& Godron, M. (1981) 'Patches and structural components for landscape ecology', BioScience 31, pp. 733-40.

Forman, R.T. \& Godron, M. (1986) Landscape ecology, Wiley, New York.

Fulcher, H. (1989) 'The Concept of Community of Interest', Discussion Paper 2, South Australian Department of Local Government. Available at http://www.dlg.nsw.gov.au/ DLG/DLGHome/documents/CommissionsTribunals/bconcept.pdf (accessed 12 December 2005).

Getches, D. (1998) 'Some irreverent questions about watershed-based efforts', Chronology and Community 2, pp. 28-34. 
Hansen A.J. \& DI CASTRI, F. (eds) (1992) Landscape boundaries: Consequences for biotic diversity and ecological flows, Springer, New York.

Hillery, G.A. (1955) 'Definitions of community: areas of agreement', Rural Sociology 20, pp. $111-24$.

Hobbs, B.F., Ludsin, S.A., Knight, R.L., Ryan, P.A., Biberhofer, J. \& Ciborowski, J.J. (2002) 'Fuzzy cognitive mapping as a tool to define management objectives for complex ecosystems', Ecological Applications 12, pp. 1548-65.

Hugo, G.P., Smailes, P., Macgregor, C., Fenton, M. \& Brunckhorst, D. (2001) Defining social catchments in non-metropolitan Australia, Bureau of Rural Sciences, Canberra.

Johnson, K., Swanson, F., Herring, M. \& Greene, S. (1999) Bioregional assessments: Science at the crossroads of management and policy, Island Press, Washington, DC.

Jones, M.A. (1977) Organisational and Social Planning in Australian Local Government, Heinemann Educational Aust., Richmond.

KEARNEY, A.R. \& KAPLAN, S. (1997) 'Toward a methodology for the measurement of knowledge structures of ordinary people: the Conceptual Content Cognitive Map (3CM)', Environmental Behaviour 29, pp. 579-617.

Kemmis, D. (1990) Community and the politics of place, University of Oklahoma Press, Norman.

Knight R.L. \& Landres, P.B. (eds) (1998) Stewardship across boundaries, Island Press, Washington, DC.

Lane, M.B., McDonald, G.T. \& Morrison, T.H. (2004) 'Decentralisation and environmental management in Australia: a comment on the prescriptions of the Wentworth Group', Australian Geographical Studies 42, pp. 103-15.

MAIDEN, H.E. (1966) The history of local government in New South Wales, Angus \& Robertson, Sydney.

MARGERUM, R.D. (1995) Examining the practice of integrated environmental management: towards a conceptual model, unpublished Ph.D. dissertation, University of WisconsinMadison.

MARshall, G. (2004) Coping with complexity in catchment management: A review of current approaches and search for new principles, RIRDC Project Working Paper 'Nesting community-based NRM for regional accountability and grass roots cooperation'.

McGinNis, M.D. (ed.) (1999) Polycentric governance and development, University of Michigan Press, Ann Arbor.

McGinnis, V.M., Wooley, W. \& Gamman, J. (1999) 'Bioregional conflict resolution: rebuilding community in watershed planning and organizing', Environmental Management 24 , pp. $1-12$.

Minami, H. \& TANAKA, K. (1995) 'Social and environmental psychology: transaction between physical space and group-dynamic processes', Environment $\mathcal{E}$ Behavior 27, pp. $43-55$.

Musgrave, W., Conner, N., Gregory, G., Sinden, J.A., Wright, V. \& Burge, B. (1985) Local Government Amalgamations in Rural New South Wales, The Rural Development Centre, University of New England, Armidale.

Muskingum Water Conservancy District (2002) Frequently asked questions about the Muskingum Water Conservancy District. Available at: http://www.mwcdlakes.com/ about.htm (accessed 16 April 2004).

NSW Department of Local Government (2004) Structural reform of local government in New South Wales, NSW Department of Local Government, Sydney.

OMERNIK, J.M. (1987) 'Ecoregions of the conterminous United States (Level II)', Annals of the Association of American Geographers 77, pp. 118-25.

OMERNIK, J.M. (1995) 'Ecoregions: a spatial framework for environmental management', in Davis, W. \& Simon, T. (eds) Biological assessment and criteria: Tools for water resource planning and decision making, Lewis, Boca Raton, FL, pp. 49-62.

OMERNiK, J.M. \& BAILEY, R.G. (1997) 'Distinguishing between watersheds and ecoregions', Fournal of the American Water Resources Association 33, pp. 1-15.

O’NeILl, K.M. (2005) 'Can watershed management unite town and country?', Society $\mathcal{E}$ Natural Resources 18, pp. 241-53. 
Parisi, D., Grice, S.M., TAquino, M. \& Gill, D.A. (2002) 'Building capacity for community efficacy for economic development in Mississippi', Fournal of Community Development \& Society 33, pp. 19-38.

Parisi, D., Taquino, M., Grice, S.M. \& Gill, D.A. (2003) 'Promoting environmental democracy using GIS as a means to integrate community into the EPA-BASINS approach', Society \& Natural Resources 16, pp. 205-20.

Parisi, D., Taquino, M., Grice, S.M. \& GiLl, D.A. (2004) 'Civic responsibility and the environment: linking local conditions to community environmental activeness', Society $\mathcal{E}$ Natural Resources 17, pp. 97-112.

Pattee, H.H. (1973) Hierarchy theory: The challenge of complex systems, Braziller, New York.

Phelps, A. (2003) Total catchment management in New South Wales: Governance rhetoric and reality, unpublished thesis, School of Social Science and Policy, University of New South Wales, Sydney.

ReEve, I. (2003) 'Principles for the nested governance of water resources', Institute for Rural Futures Occasional Paper 2003/1. Available at http://www.ruralfutures.une.edu.au/ publications/occpapers/occpapers.htm (accessed 7 February 2006).

Reeve, I., Frost, L., Musgrave, W. \& Stayner, R. (2002a) Agriculture and natural resource management in the Murray-Darling Basin: A policy history and analysis, published report to the Murray-Darling Basin Commission, Institute for Rural Futures, University of New England, Armidale and Murray-Darling Basin Commission, Canberra.

Reeve, I., Marshall, G. \& Musgrave, W. (2002b) Resource governance and ICM, published report to the Murray-Darling Basin Commission, Institute for Rural Futures, University of New England, Armidale and Murray-Darling Basin Commission, Canberra.

REID, T.S. \& MuRPhy, D.D. (1995) 'Providing a regional context for local conservation action: a natural community conservation plan for the southern California coastal sage scrub', BioScience Supplement 1995, pp. 84-90.

Schusler, T.M., Decker, D.J. \& Pfeffer, M.J. (2003) 'Social learning for collaborative natural resource management', Society \& Natural Resources 16, pp. 309-326.

SHANNON, M.A. (1998) 'Understanding social organizations and institutions', in Naiman, R.J. \& Bilby, R.E. (eds) River ecology and management: Lessons from the Pacific coastal ecoregion, Springer, New York, pp. 529-51.

SLOCOMBE, D.S. (1993) 'Implementing ecosystem-based management: development of theory, practice and research for planning and managing a region', BioScience 43, pp. $612-22$.

SMAILES, P.J. (1987) 'Making boundaries make sure: some principles for defining small-area rural census districts' in Conacher, A. (ed.) Readings in Australian geography, Proceedings of the 21 st Conference of the Institute of Australian Geographers, Perth.

SMAILES, P.J. (1999) Community social area identification: A case study of rural South Australia, report to the Bureau of Rural Sciences, Department of Geographical and Environmental Studies, University of Adelaide, Adelaide.

STEDMAN, R.C. (2003) 'Is it really just a social construction?: the contribution of the physical environment to sense of place', Society E Natural Resources 16, pp. 671-86.

Stokols, D. \& Shumaker, S.A. (1981) 'People in places: a transactional view of settings', in Harvey, J.H. (ed.) Erlbaum, Hillsdale, NJ, pp. 441-88.

Syme, G. J., Butterworth, J.E. \& Nancarrow, B.E. (1994) National whole catchment management: A review and analysis of processes, Occasional Paper 01/94, Land and Water Resources Research and Development Corporation, Land and Water Australia, Canberra.

TONTS, M. \& ATHERLEY, K. (2005) 'Rural restructuring and the changing geography of competitive sport', Australian Geographer 36, pp. 125-44.

TuAn, Y.F. (1974) Topophilia: A study of environmental perception, attitudes, and values, Englewood Cliffs, NJ: Prentice Hall.

Urban, D.L., O'Neill, R.V., \& Shugart, JR. H.H. (1987) 'Landscape Ecology: A hierarchical perspective can help scientists understand spatial patterns', BioScience 37, pp. $119-127$.

WALDO, D. (1984) The administrative state: a study of the political theory of American public administration, Holmes \& Meier, New York.

WALMSLEY, D.J. (1977) 'Communities of Interest and Local Government Boundaries'. Shire and Municipal Record 70, pp. 55-57. 
WeBler, T. \& Tuler, S. (1999) 'Integrating technical analysis with deliberation in regional watershed management planning: applying the National Research Council approach', Policy Studies 27, pp. 530-43.

Wiken, E. (1986) 'Terrestrial ecozones of Canada', in Ecological land classification series No. 19, Environment Canada, Ottawa.

Wilkinson, K.P. (2000) The rural community in America, Social Ecology Press, Middleton, WI. 